\title{
DE
}

DE GRUYTER

OPEN

Arch. Min. Sci. 62 (2017), 2, 301-311

Electronic version (in color) of this paper is available: http://mining.archives.pl

DOI 10.1515/amsc-2017-0023

IWONA JONCZY*1, ŁUKASZ GAWOR*

\section{COAL MINING AND POST-METALLURGIC DUMPING GROUNDS AND THEIR CONNECTIONS WITH EXPLOITATION OF RAW MATERIALS IN THE REGION OF RUDA ŚLĄSKA}

\author{
ZWALOWISKA ODPADÓW GÓRNICZYCH I HUTNICZYCH ORAZ ICH ZWIĄZKI \\ Z EKSPLOATACJĄ SUROWCÓW NA TERENIE RUDY ŚLĄSKIEJ
}

\begin{abstract}
Characteristics of mining and metallurgical waste dumps in Ruda Śląska was presented in this article. Special attention was paid to the relationship of waste material accumulated on the dumps with resources exploited on studied area. The possibilities of dumps management were also traced and two directions were indicated. The first one is associated with forming a biological covering on the dumps and the second one - with the dumps liquidation and with recovery areas now occupied by the dumps and thus with the secondary use of material collected on them.
\end{abstract}

Keywords: coal mining dumping grounds, post-metallurgic dumping grounds, Ruda Śląska

W artykule scharakteryzowano odpady górnicze i hutnicze ze zwałowisk w Rudzie Śląskiej. Szczególną uwagę zwrócono na związek odpadów zgromadzonych na zwałowiskach z surowcami eksploatowanymi na badanym obszarze. Prześledzono również możliwości zagospodarowania zwałowisk, wskazano dwa kierunki: pierwszy z nich związany jest z utworzeniem na zwałowiskach obudowy biologicznej, drugi natomiast $-\mathrm{z}$ likwidacją zwałowisk i odzyskiem obszarów obecnie zajmowanych przez zwałowiska, a tym samym z wtórnym wykorzystaniem zgromadzonych na nich odpadów.

Słowa kluczowe: zwałowiska odpadów górniczych, zwałowiska odpadów hutniczych, Ruda Śląska

\section{Introduction}

Upper Silesia is a region with an extraordinarily rich history of mining and metal industries. It isn't, however, always possible to reach written accounts confirming the existence of industrial plants or describing the history of mining and processing. The documentation is, however, consti-

* INSTITUTE OF APPLIED GEOLOGY, FACULTY OF MINING AND GEOLOGY, SILESIAN UNIVERSITY OF TECHNNOLOGY, AKADEMICKA STR. 2, 44-100, GLIWICE, POLAND

$1 \quad$ CORRESPONDING AUTHOR: Iwona.Jonczy@posl.p1 
tuted by dumping grounds of waste material resulting from mining and metal production processes. The location of the grounds, the type of the waste material and its chemical composition may provide valuable data concerning the sort of the ore mined and used in the production process.

The development of Silesia has been largely influenced by the rich resources which have contributed to the industrial character of the region. Besides large-scale coal mining, which is still continued, the area used to be a place of metal ores exploitation, especially sulphide and galmei $\mathrm{Zn}-\mathrm{Pb}$ ores (as also silver occurring with them) and bog iron ores. It is the ore mining that relates to the oldest industrial traditions in the Upper Silesia. Ruda Śląska is one of the Upper Silesian cities characterized by a strong adherence to both coal and ore mining traditions (Fig. 1,2).

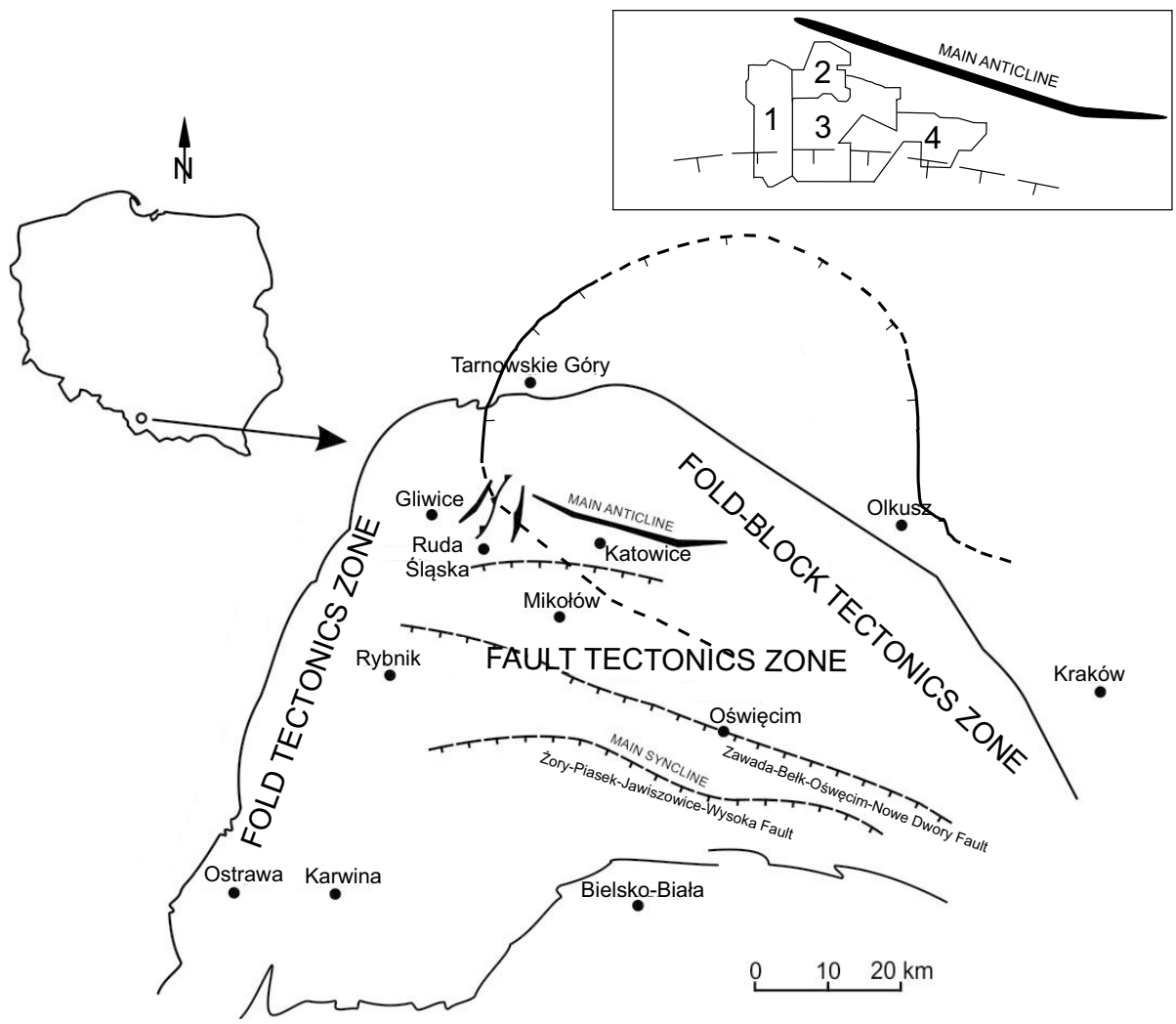

Fig. 1. Sketch of location of Ruda Śląska in Upper Silesian Coal Basin (after Probierz \& Borówka, 2009, modified). Explanations: - - - - range limit of ore-bearing dolomites (details Fig. 2);

1-4 areas of studied hard coal mines (1 - Bielszowice; 2 - Pokój; 3 - Halemba and Polska Wirek, actually Halemba; 4 - Śląska, actually Wujek)

\section{Historical sketch}

The first documented mentions of $\mathrm{Zn}-\mathrm{Pb}$ mining relate to the Bytom region, which transformed from a small settlement in the $12^{\text {th }}$ century to a mining and trade city in the $14^{\text {th }}$ century. 


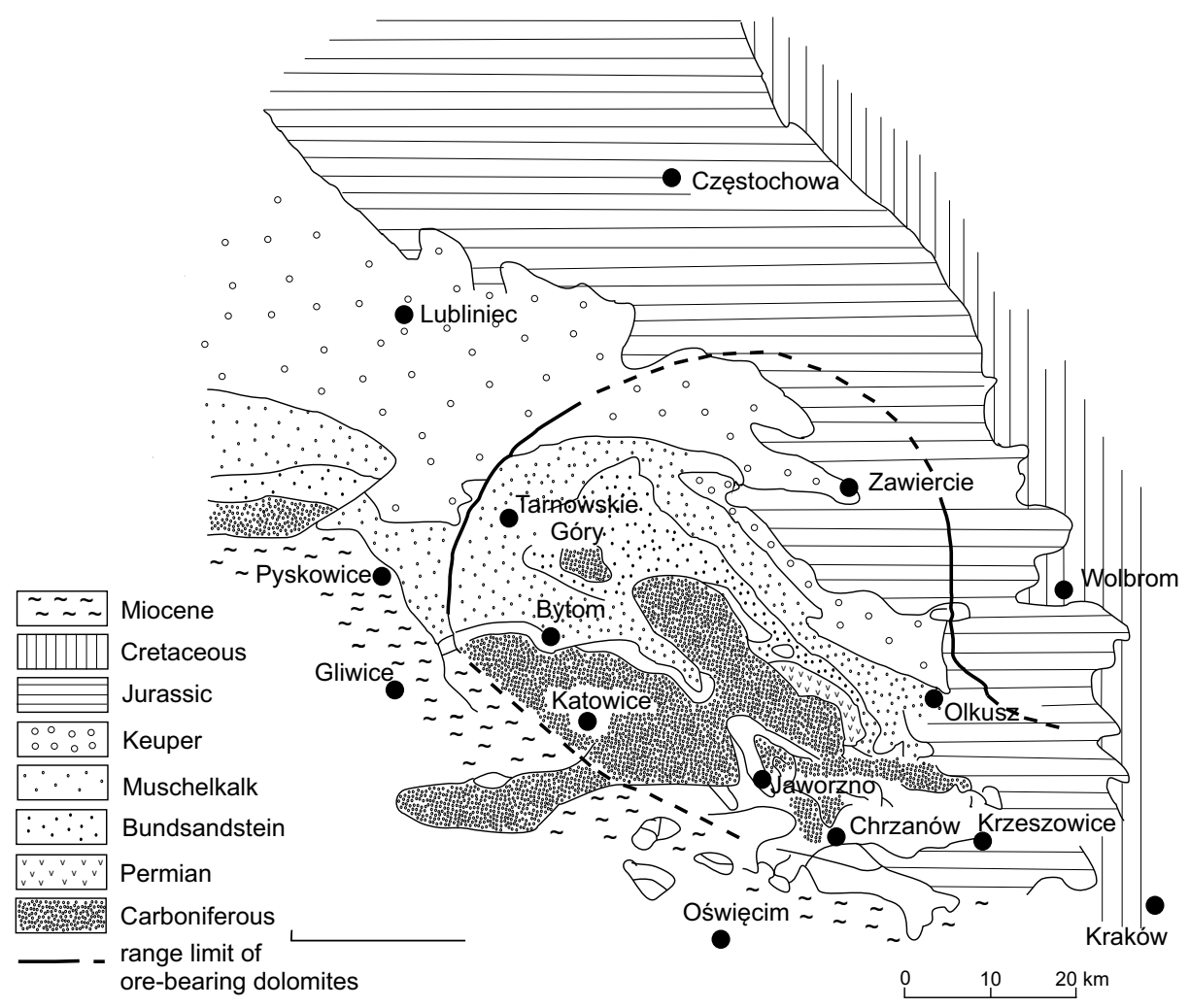

Fig. 2. Sketch of range limit of ore-bearing dolomites (after Gabzdyl, 1995, modified)

The $\mathrm{Zn}-\mathrm{Pb}$ ores were dressed in 180 washers and the lead and silver melting was conducted in 30 mills (Pazdur, 1960; Probierz, 2001). In the subsequent years, the range of $\mathrm{Zn}-\mathrm{Pb}$ ores exploitation extended to further areas. The settlements and villages which are now quarters of the Ruda Śląska city are a good example of such grounds.

The oldest source providing information regarding a place named Ruda is the Papal Bull of Pope Adrian IV dated 1155. Further mentions are from 1595 and 1305 and come from the socalled Registrum Vyasdense - the list of estates and incomes of the Breslau bishopric. The first information on the mining and metal production industries, however, prove that since middle ages a forgery smelting lead existed at the area of the present Ruda. Since 1401 the forging plant was in the possession of the Rudzki brothers, who have inherited the town. After 1455, probably due to depletion of resources, it has been transformed into an iron forging plant. The intensive development of mining and $\mathrm{Zn}-\mathrm{Pb}$ metal production took place in $18^{\text {th }}$ and $19^{\text {th }}$ century (Ratka, 1995).

During this time, on the territory of today Ruda Śląska several zinc works existed, for example: Dobra Nadzieja (1825-1860), Zorza Poranna (1830-1860), Godula (1815-1919), MiłośćNadzieja (1834-1925), Rozamunda (1838-1931), Hugo (1812-1932).

The extraction of locally present bog iron ores was then related to the exploitation of $\mathrm{Zn}-\mathrm{Pb}$ ores. In the area of Upper Silesia, in 1769, except for numerous places where the exploitation was not registered, there were a dozen or so underground iron ore mines which served 14 furnaces 
of the time. The sources provide that in that time in Halemba there was a large furnace which allows to assume that mines providing resources operated in the vicinity. Moreover, mentions of import of bog iron ores from Donnersmarck's mine in Nakło have been preserved (Pazdur, 1960; Popiołek, 1965; Dworak \& Ratka, 1985; Dworak, 1995). The Donnersmarcks represented Silesian noble family from the former region of Spiš in Upper Hungary, now belonging to Slovakia. The founder of the family was Henckel de Quintoforo in the 14/15th century.

The beginning of underground coal mining in Upper Silesia is dated on the end of 18th century, when there was announced a mining decree of King of Prussia. The first coal mine in the neighborhood of present coal mine "Murcki-Staszic" in Katowice started its exploitation in 1740. The oldest coal mines in Upper Silesia represent: "Wawel" (in Ruda Śląska), "Ruhberg" (in Mysłowice) - beginning of exploitation in 1770, "Reden" in Dąbrowa Górnicza (1785), "Król" in Królewska Huta and "Królowa Luiza" in Zabrze (1791). The coal statistics started in Upper Silesia in the year 1769. The oldest exploitation occurred in the zones of carboniferous outcrops and in shallow coal seams, which depth reached ca. 80 meters (Probierz, 2001; Jaros, 1965; Jaros, 1984).

\section{Dumps}

\section{a. Post metallurgic dumps}

The imprints of history of ore mining in Ruda Śląska may be found in the remaining industrial dumping grounds. Despite the lapse of years (these are often more than a hundred years old), the grounds still exist and constitute an inseparable element of the Upper-Silesian landscape. These are mostly smelter waste dumps; shallow exploitation and opening many small exploitation fields was not advantageous for the formation of large amounts of mining waste, so the dumps have not been preserved. These two branches, however: mining and iron and steel industries were always closely interconnected. Due to limited communication possibilities in the former centuries, it was more profitable to construct the entire infrastructure including forging plants at the place of exploitation. The smelters were located as close to calamine mines and coal mines as possible (Boryczka \& Blacha, 2002 a, b).

On the area occupied by today Ruda Śląska city some dumps after the industrial activities connected with $\mathrm{Zn}-\mathrm{Pb}$ industry can be found:

- dump after Rozamunda zinc smelter in Nowy Bytom, Niedurny street (Chodyniecka \& Bartela, 1999); currently reclaimed (area 1,7 ha);

- dump on the Stara street; in years 1854-1919 a large Godula zinc smelter was existed here, which was built by collaborators of Karol Godula. They worked on behalf of the Joanna Gryzik, who was Karol Godula heiress. The smelter gave rise to the village of the same name, transformed later in the district of today Ruda Śląska (area 6,5 ha);

- dump in Wirek, after production of Hugo zinc smelter, Nowary street (area 10,5 ha), (Fig. 3);

- and also dumps: on the Ceramiczna street and on the Bałtycka street.

The material accumulated on the dumps is a record of mining and iron and steel industries history in the past centuries. Detailed research has been conducted on the Wirek quarter dump (Jonczy, 2006). The waste was not disposed selectively, the dumps thus constitute a blend of 


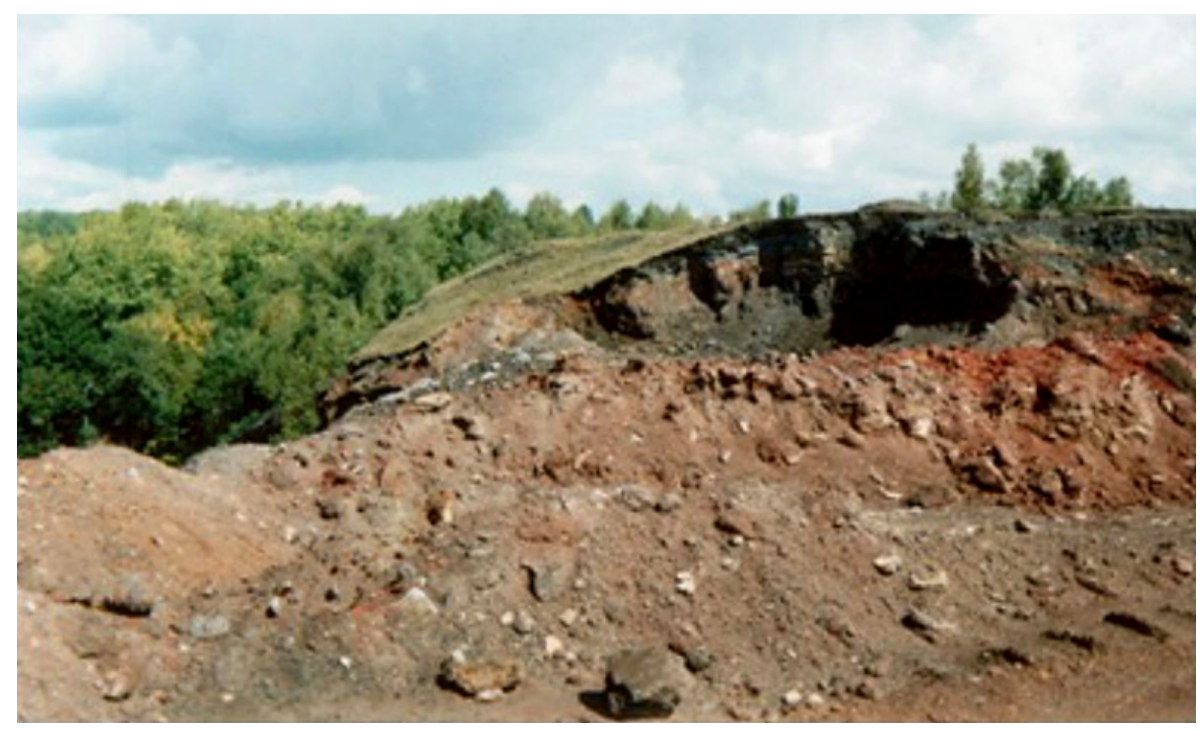

Fig. 3. Weathered slags on the dump in Ruda Śląska-Wirek, Nowary street (photo I. Jonczy)

material in which slag - highly slaked due to chemical and physical weathering, glazed elements of the smelting materials, mining waste (mostly shales), and elements of furnace bodies may be found. The largest part of the waste material is constituted by slag. The slag is characterized by diversified colors; from red through brown to black. The surface of the slag is often covered by secondary crystallization blooms of calcite, gypsum and barite (Jonczy, 2013). It is a brittle material with a close-grained structure. The tests of the chemical composition indicated that the slag contains high amounts of zinc and lead as well as iron which occur mostly as oxides. Chemical research showed that this slag contains a considerable amounts of: zinc (6270-83700 ppm, average of 20 analyzes is $31761 \mathrm{ppm}$ ) and lead (5340-29385 ppm, average of 20 analyzes is $15898 \mathrm{ppm}$ ) and iron, which occurs as iron oxides: $\mathrm{Fe}_{2} \mathrm{O}_{3}$ 13.43-25.62\% (average $20.79 \%$ ) and $\mathrm{FeO} 3.67-12.47 \%$ (average 6.90\%) (Jonczy, 2006).

The high concentration of $\mathrm{Zn}$ and $\mathrm{Pb}$ in the waste materials, the ores of which were supposed to be exploited, is an indication that the methods and technology of obtaining elements from the extracted ores prevailing at that time were not very precise. A part of the elements ended along waste accumulated on a nearby dumping ground. The presence of iron compounds may be a sign that the raw material used in Hugo smelter was red calamine rich in oxide and hydroxide iron. The dumping ground may have also been used for wastes coming from the processing of local bog iron ores. Calamine ores occurred at the surface or at low depths and caused no trouble in exploitation. The crisis caused by calamine resources depletion, which occurred in the second part of the $19^{\text {th }}$ century, has resulted in the use of wastes accumulated on the dumping sites and the improvement of ore smelting technologies. Moreover, due to the depletion of a given raw material, the forgeries were often modified to process another ore, one that would be available. The situation has changed when large deposits of sulfide ores - sphalerite - have been found in Upper Silesia. (Pazdur, 1960; Popiołek, 1965; Paulo \& Strzelska-Smakowska, 1994). This also explains, to some extent, why the material on old dumping grounds is so diverse. 


\section{b. Coal mining dumps}

According to the latest research and field works in the Upper Silesian Coal Basin there are ca. 220 coal-mining waste dumps, covering the surface of over 4000 ha. The highest concentration of the dumps occurs in the central part of USCB e.g. in Bytom, Ruda Śląska, Zabrze and Katowice as well as in the south-western part of USCB e.g. Rybnik and Jastrzębie-Zdrój. The largest dumps cover the area of over 250 ha (Central Coal Mining Dumps in Smolnica and Knurów).

The types of generations of coal mining waste dumps are connected with their origination and development of preparation technologies. There are three categories of the dumps, which are: conical dumps (without compaction, the most dangerous for the natural environment), tabular dumps (objects built with compaction in a form of tabular mountain) as well as landscape dumps (fully reclaimed objects, compacted, built with the design of the slopes which is matched to the landscape (Gawor, 2011; Gawor et al., 2011).

In the paper there is presented a case study of coal mining waste dumps in Ruda Śląska, because this town represents one of the regions with the highest density of waste dumps, both post-mining and post-metallurgic.

In the table 1 there are presented all waste dumps after hard coal mining, which cover the surface of 284,54 ha.

TABLE 1

Coal mining waste dumps in Ruda Śląska

\begin{tabular}{|c|c|c|c|}
\hline Coal mining waste dump & City & Coal mine & Surface (ha) \\
\hline $\begin{array}{l}\text { Coal mining waste dump Cegielniana } \\
\text { street }\end{array}$ & Ruda Śląska & KWK “Śląsk” & 12,0 \\
\hline Coal mining waste dump Kalinowa street & Ruda Śląska & KWK "Śląsk" & 3,14 \\
\hline Coal mining waste dump Panewniki & $\begin{array}{l}\text { Ruda Śląska/ } \\
\text { Mikołów }\end{array}$ & KWK "Halemba" & 118,4 \\
\hline Levelling of pit in Bielszowice & Ruda Śląska & KWK "Halemba" & 9,5 \\
\hline $\begin{array}{l}\text { Coal mining waste dump by the shafts } \\
\text { Grunwald }\end{array}$ & Ruda Śląska & KWK "Halemba" & 7,1 \\
\hline Coal mining waste dump Klara & Ruda Śląska & KWK "Pokój” & 21,2 \\
\hline Coal mining waste dump Czesław & Ruda Śląska & KWK "Pokój" & 5,6 \\
\hline Coal mining waste dump Nowa Klara & Ruda Śląska & KWK "Pokój” & 3,6 \\
\hline Coal mining waste dump "R" & Ruda Śląska & KWK "Pokój” & 27,1 \\
\hline Coal mining waste dump "Mikołaj" & Ruda Śląska & KWK "Pokój” & 3,5 \\
\hline Coal mining waste dump 12,13 & Ruda Śląska & KWK "Pokój” & 2,7 \\
\hline Coal mining waste dump 1 and 5 & Ruda Śląska & KWK "Polska Wirek" & 6,3 \\
\hline Coal mining waste dump 2 & Ruda Śląska & KWK "Polska Wirek" & 9,3 \\
\hline Coal mining waste dump nr 3 & Ruda Śląska & KWK "Polska Wirek" & 2,5 \\
\hline Coal mining waste dump nr 4 & Ruda Śląska & KWK "Polska Wirek" & 13,9 \\
\hline Coal mining waste dump Borowa II & Ruda Śląska & KWK "Bielszowice" & 30,0 \\
\hline Coal mining waste dump Halembska street & Ruda Śląska & KWK "Bielszowice" & 8,7 \\
\hline Total: & & & 284,54 \\
\hline
\end{tabular}

Source: Self study 
Geological composition of waste material disposed in coal mining dumping grounds represents predominantly sedimentary rocks - siltstones (40-98\%), mudstones (2-40\%) and sandstones $(0-33 \%)$ as well as coal shales (2-25\%) and significant percentage of coal particles (3-10\%). The coal content is very important because of potential environmental hazards, particularly dump fires. On the other hand coal content may be a parameter which enables considering of waste dump as anthropogenic secondary deposit. The relationship between coal quality, petrographic composition of wastes and regarding a dump as potential secondary deposit is presented in following paragraphs (Gawor, 2011).

Described dumps, both mining and metallurgic are presented on the map below (Fig. 4).

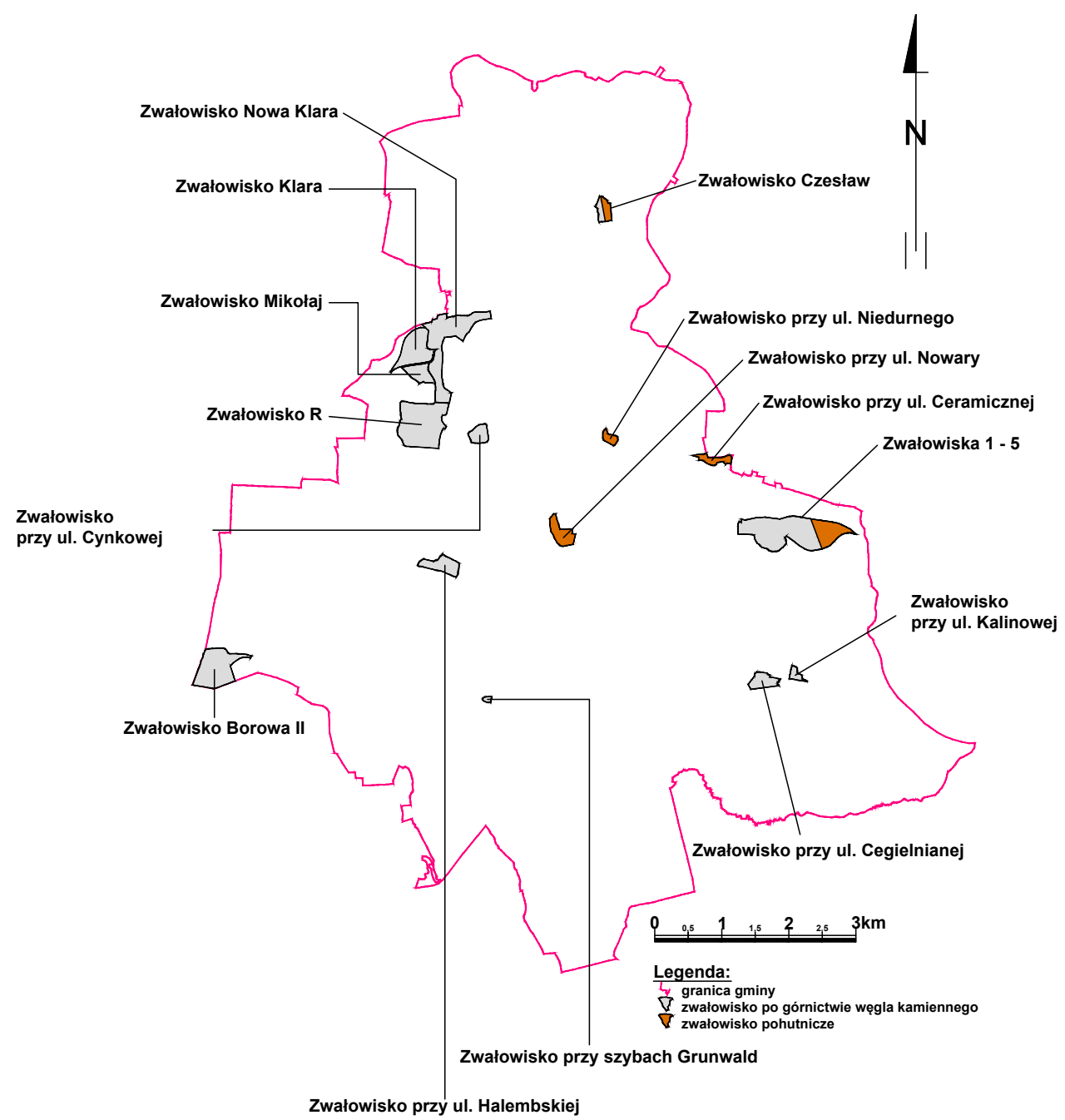

Legend: Zwałowisko - waste dump; zwałowisko po górnictwie węgla kamiennego - coal mining waste dump; zwałowisko pohutnicze - post metallurgic waste dump; granica gminy - commune border. Source: self study.

Fig. 4. Post mining and post metallurgic dumps in Ruda Śląska 


\section{Dumps reclamation}

The waste material accumulated on $\mathrm{Zn}-\mathrm{Pb}$ waste dumping grounds, as opposed e.g. to metallurgical slag, does not always provide perspectives of reuse. The high degree of weathering of the wastes and significant amounts of heavy metals often disqualify the slag as a material for the production of aggregate. It is a material which is deemed to be one of the most environmentally noxious (Janecka \& Sobik-Szołtysek, 2009). Due to the lack of treatment possibilities of the $\mathrm{Zn}-\mathrm{Pb}$ wastes, it is important to secure the disposal grounds, so they would not become a source of elements migrating to the environment. Also, the uncovered top surfaces and slopes pose a problem, as the waste material is deflated and transported at large distances.

Examples of securing the old zinc dumps by biological rehabilitation may be found in Silesia. The aforementioned dumping site in the Nowy Bytom, a Ruda Śląska quarter, at Niedurny street may be an example of such a dump. The investment, conducted thanks to EU subsidies, constitutes a good example of a pro-ecological activity. A new shape has been given to the dump so as to ensure the retention of rainwater and the so-shaped area has been covered with a sealing layer of clay and biological rehabilitation has been performed.

Similar rehabilitation works are also performed in Świętochłowice, where the longstanding activity of the "Silesia" Metallurgical Plant had a detrimental effect on the environment. In the north-western part of the city, at Chrobry street, smelter waste materials had been accumulated for years, namely: slag from muffle furnaces, parts of used ceramic muffles as well as wastes produced in coal gasification in gas generators and slag from the boiler room. Presently, rehabilitation works are conducted. The works consist in leveling the surface of the dump by distributing gangue and biological covering using a blend of post-flotation rocks, stabilized sludge and earth from excavation.

Large-scale rehabilitation works are also conducted at the premises of "ZGH Bolesław" mining and metallurgical plants with their seat in Bukowno (Ciarowska \& Hanus-Fajerska, 2011).

Nowadays, the problem of post-mining waste dumps' reclamation has become quite serious. Technical reclamation is strictly connected to environmental hazards. Fire hazards belong to the most dangerous environmental impacts of coal mining waste dumps. If waste material is not compacted, and compacting is also a part of technical reclamation, this may cause a spontaneous combustion (mostly in old conical dumps) (Kuna-Gwoździewicz, 2013). Fire hazards at coal-mining waste dumps are also strictly related to the ways of biological reclamation, e.g. afforestration. Trees make waste material more loose and enable access of oxygen to the dump, which results in higher self-ignition hazard (Fig. 5)

One of the technical reclamation methods is levelling and so called "micro-levelling". Good and successful examples of such processes may be the areas of Klara and Nowa Klara waste dumps, where the degraded areas between old dumping grounds have been levelled using coal mining waste. In the area recovered in that way there are now industrial zones - e.g. construction sites and commercial investment grounds.

As far as reclamation and management of post-mining dumping grounds are concerned, it is possible and even necessary to recover coal from these objects. Coal recovery reduces the risk of self-ignition and fires of the dumps, which makes the described objects potential places to be developed as sport and recreation areas. In the past there were examples of successive recovery of coal from various dumps (e.g. the main mining waste dump in Smolnica, waste dumps in Buków and Czerwionka-Leszczyny). Some of the dumps are still being exploited - one of the 


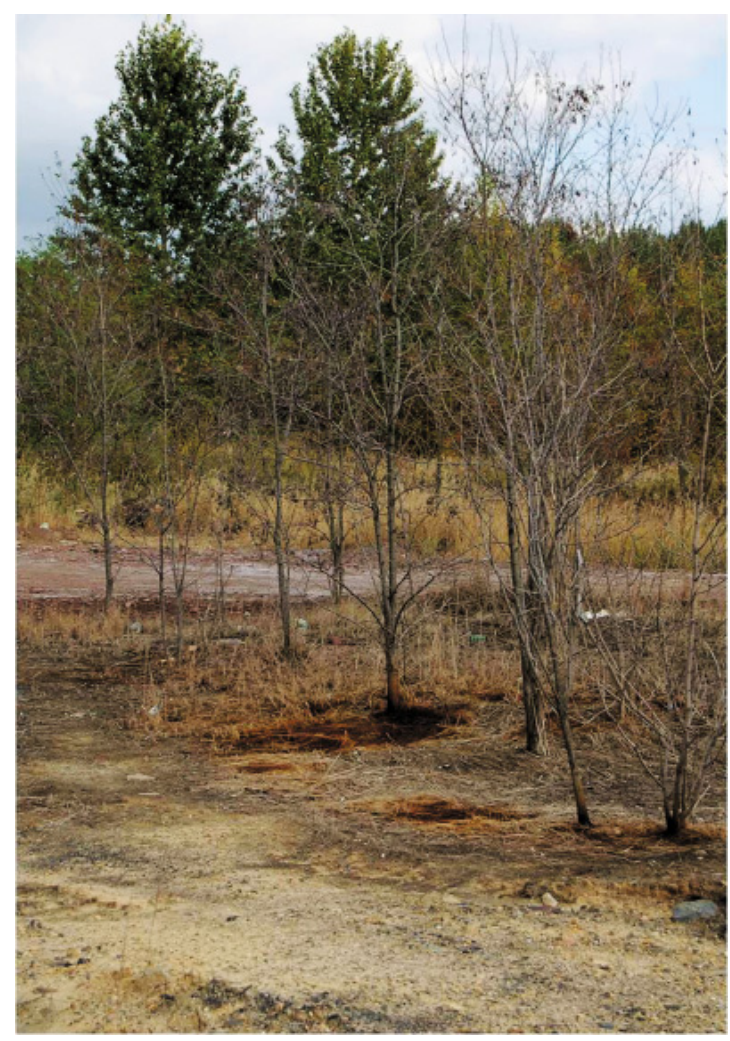

Fig. 5. Fire seats near tree`s trunks on the coal mining waste dump in Ruda Śląska (photo L. Gawor)

examples can be the waste dump in Panewniki, which is partially situated in Ruda Ślaska, and the main waste dump in Knurów (Gawor \& Main, 2007).

An analysis was performed in order to determine the possibilities of considering waste dumps as secondary deposits, where the objects in Ruda Śląska were used as examples.

The valorisation analysis concerning potential recovery of coal took into consideration the following parameters:

- quality of coal extracted by the mines,

- self-ignition processes occurring on the dumps,

- surface and accessibility of the dumps.

Coal extracted by the Halemba coal mine may be classified as belonging to the following types: $34.1,34.2,35.1,35.2 \mathrm{~A}$ and $35.2 \mathrm{~B}$ and rarely 37.1 , however, coal of 34 type is the most common. Coal extracted in the Halemba coal mine is characterized by high ash content, reaching $50 \%$, low moisture content (up to $1.5 \%$ ), calorific value in the range of $21.0-33.0 \mathrm{MJ} / \mathrm{kg}$, and low sulphur content ( 0.2 to $1.2 \%$, majority lower than $1.0 \%$ ).

In the Pokój coal mine there is mainly energetic coal of types 32,33 and in the minority 34 . These types of coal are characterized by low ash content, mean value $9.27 \%$, mean calorific value $29.0 \mathrm{MJ} / \mathrm{kg}$, mean total sulphur content $0.66 \%$ and combustible sulphur content $0.56 \%$. 
As far as the Bielszowice coal mine is concerned, there is mainly energetic coal of types $31,32.1$ and 32.2 as well as coking coal of types $33,34,35.1$ and 35.2. The average ash content is $15.83 \%$, mean calorific value is within the range of $6784 \mathrm{cal} / \mathrm{g}$, mean total sulphur content reaches $1.3 \%$ and combustible sulphur content amounts to $0.48 \%$.

As for the aforementioned parameters, self-ignition processes, as well as surface and accessibility of the dumps, the most suitable objects for potential recovery of coal are the following: Klara coal mining waste dump, " $\mathrm{R}$ " coal mining waste dump, Borowa II coal mining waste dump and Panewniki coal mining waste dump. Dumping grounds at the Śląsk and Polska Wirek coal mines have not been taken into consideration because of their fairly small areas. The object where the pit in Bielszowice was levelled using coal mining waste has not been taken into consideration because of self-ignition and fire processes.

The results obtained are reliable, which has been confirmed by the fact that coal is presently recovered from the waste dump in Panewniki.

\section{Conclusions}

As a result of intensive mining and metallurgical activities, the problem of numerous dumping grounds in Upper Silesia is still an issue we have to face; waste dumps constitute an integral part of the Upper Silesia landscape.

However, today, in accordance with broad principles of the environmental policy, one may observe two directions of actions taken in relation to dumps. The first concerns reclamation of dumping grounds and it is associated with a biological covering formation on the dumps, which allows to transform dumps into recreation areas.

The second direction assumes dumping grounds, and thus using the waste material collected on them e.g. as a material for the production of different kinds of aggregates. This course of action is also associated with the recovery of ground currently occupied by dumps, especially since most of them are located in urban centres. Such places may be found in some Silesian cities, but in relation to the number of all waste dumps located in the Upper Silesia area, there are still quite few examples.

\section{References}

Boryczka A., Blacha L., 2002 a. Hutnictwo cynku na Śląsku do końca XIX wieku. Rudy i Metale Nieżelazne, nr 8, s. 369-374. Boryczka A., Blacha L., 2002 b. Hutnictwo cynku na Śląsu w XX wieku. Rudy i Metale Nieżelazne, nr 12, s. 618-622. Ciarowska K., Hanus-Fajerska E., 2011. Porównanie właściwości fizyko-chemicznych i biologicznych materiałów poflotacyjnych obsadzonych zróżnicowanym materiałem roślinnym. Nauka Przyroda Technologie, t. 5, z. 6, s. 1-10.

Chodyniecka L., Bartela A., 1999. Charakterystyka mineralogiczna zwałowiska odpadów hutniczych po produkcji cynku „Rozamunda” i jego wplyw na środowisko. Zeszyty Naukowe Wydziału Budownictwa i Inżynierii Środowiska Politechniki Koszalińskiej, nr 15, s. 403-411.

Dworak J.S., 1995. Karol Godula. Państwowy Instytut Naukowy, Instytut Śląski w Opolu, Związek Górnośląski, koło Nowy Bytom w Rudzie Śląskiej, Opole-Ruda Śląska.

Dworak J.S., Ratka A., 1985. Ruda Śląska-przewodnik. Towarzystwo Przyjaciół Miasta Rudy Śląskiej, Oddział Miejski Polskiego Towarzystwa Turystyczno-Krajoznawczego w Rudzie Śląskiej, Ruda Śląska.

Gabzdyl W., 1995. Geologia złóż. Skrypty Uczelniane Politechniki Śląskiej, nr 1891. 
Gawor, Ł., Main, M., 2007. Ausgewählte Umweltprobleme im Ruhrgebiet und im Oberschlesischen Kohlenbezirk (GZW) am Beispiel von Bergehalden. In: Veröffentlichungen von der 16. Tagung für Ingenieurgeologie und vom Forum Junge Ingenieurgeologen, Bochum, p. 95-103.

Gawor Ł., 2011. Der Einfluss von Rechtsvorschriften auf Rekultivierung und Folgenutzung von Bergehalden am Beispiel des Oberschlesischen Steinkohlebeckens und des Ruhrgebietes. Monografia, Wydawnictwo Politechniki Śląskiej, Gliwice, 2011.

Gawor Ł., Jankowski A. T., Ruman M., 2011. Post-mining dumping grounds as geotourist attractions in the Upper Silesian Coal Basin and the Ruhr District. [in:] Moravian Geographical Reports, vol. 19, no. 4, p. 61-68.

Janecka B., Sobik-Szołtysek J., 2009. Badania przydatności technik remediacji terenów zdegradowanych działalnościa przemystu cynkowo-ołowiowego. Inżynieria i Ochrona Środowiska, t. 12, nr 4, s. 281-294.

Jaros J., 1965. Historia górnictwa węglowego w Zagłębiu Górnośląskim do 1914 roku. Wrocław-Kraków.

Jaros J., 1984. Stownik historyczny kopalń węgla na ziemiach polskich. Śląski Instytut Naukowy, Katowice.

Jonczy I., 2006. Charakterystyka mineralogiczno-chemiczna zwałowiska odpadów poprodukcyjnych huty cynku i ołowiu w Rudzie Śląskiej-Wirku oraz jego wptyw na środowisko. Monografia, Wydawnictwo Politechniki Śląskiej, Gliwice.

Jonczy I., 2013. Żu̇̇le po produkcji żelaza, cynku i ołowiu w świetle badań mineralogicznych. Przegląd Górniczy, nr 3 , s. 52-56.

Kuna-Gwoździewicz P., 2013. Emission of polycyclic aromatic hydrocarbons from the exhalation zones of thermally active mine waste dumps. In: J. Sust. Min., vol. 12, no 1, p. 7-12.

Pazdur J. (praca zbiorowa), 1960. Zarys dziejów górnictwa na ziemiach polskich. Wydawnictwo Górniczo-Hutnicze, Katowice.

Popiołek K., 1965. Górnośląski przemyst górniczo-hutniczy w drugiej połowie XIX wieku. Śląski Instytut Naukowy w Katowicach, Katowice-Kraków.

Probierz K., 2001. Górnictwo na cenzurowanym. Wydawnictwo Politechniki Śląskiej, Gliwice.

Probierz K, Borówka B., 2009. Weryfikacja ilościowa i jakościowa zasobów węgla kamiennego w wytypowanych kopalniach Górnośląskiego Zagłębia Węglowego. Wydawnictwo Politechniki Śląskiej, Gliwice.

Ratka A., 1995. Ruda Śląska (1295-1995). Urząd Miejski w Rudzie Śląskiej i Towarzystwo Przyjaciół Rudy Śląskiej.

Suchnicka H., 2000. Shear strength properties of waste material several years after disposal. Archives of Mining Sciences, vol. 45, no 1, p. 47-71.

Szczepańska J., Twardowska I., 1999. Distribution and environmental impact of coal mining wastes in Upper Silesia, Poland. Environ. Geol., vol. 38, issue 3, p. 249-258.

http://rudaslaska.com.pl/i,rekultywacja-haldy-zakonczona,200274,734273.html\#ixzz2zbmxaw8I

http://www.swietochlowice.pl/mieszkaniec-ochrona-srodowiska-rekultywacja-haldy-swietochlowic.html 